\title{
Kendari Port Development: The Meeting Point of Shipping and Trade Route in East Coast of Sulawesi, 1831-1945
}

\author{
M. Mulki Mulyadi Noor \\ Department of History, Faculty of Humanities, \\ Universitas Indonesia, Indonesia
}

\begin{abstract}
This article analyses the ups and downs of Kendari port development since 1831 until Japanese occupation ended in Indonesia. This study tries to place Kendari port as the main port with areas that become the link of traditional and modern trade routes at the east coast of Sulawesi. Moreover, Kendari has become Collecting Center port since the 16th century, therefore, the connectivity between Kendari port and other regions is quite close. This study used primary source in the form of official record of the colonial government and secondary source in the form of publication related to the topic of the study. The study found that traditionally the trade relation of Kendari port with other regions originated from two routes, namely Wawonii island and

Received:

December 12, 2018

Revised:

December 22, 2018

Accepted:

January 22, 2019

\section{Corresponding Author:}

mulkinoor@gmail.com Bokori island, while in the colonial period the role of the Dutch government made Kendari as a modern port so that the port developed rapidly as one of the links for KPM shipping and trade and Bugis traders who were still active until the 20th century. This role continued in Japan, but it was no longer a trading port, but as a Japanese naval base.
\end{abstract}

Keywords: Kendari Port; Shipping and Trade; Maritime; Sulawesi; Colonial.

\section{Introduction}

Geographically, Archipelago is an area that has dynamic character in terms of geography and geopolitics where each other is connected and interdependent through sea route. Sea is considered as a link between different regions and a unifier, not as a separator. According to Masashi (2009), port is a place that can be found everywhere in the world. Before train, car and airplane exist, ports were at the center of political and economic activities and a place where the exchanges of new goods, art, ideas and technology were introduced and developed. Ports are usually owned by an empire or country but at the same time belong to the maritime world that connects them to the outside world (Masashi, 2009, p. 20). Therefore, the port's role is very important as a crucial connecting point for ships that want to rest and continue their journey to other places, so that technically a port must be connected to other areas which have become the trade and shipping routes at that time.

In addition, the role of ships as a means to transport people and goods in the sea already exists along with the appearance of the port itself. The oldest written evidence in the archipelago mentioning the use of boats as a means of sea transportation is found in Kedukan Bukit inscription dated June 16, 682 AD. During the same period, the reliefs from Borobudur portrayed the ship and outrigger boats. Pelras (2006) mentioned that based on his analysis of La Galigo text, in the 11th Century the traders from Java (Majapahit), Sunda and Sumatra (the Kingdom of Malay, the successor of Srivijaya) had gone back and forth to trade in Sulawesi island by using great ships.

At La Galigo there was Sawerigading's log book by a ship that was as large as land (Wakka Tana) and it illustrated the existence of sturdy Bugis ships that navigated the oceans of that era (Pelras, 2006: 8086). Likewise, the interaction between Javanese traders who went back and forth to Sulawesi in searching for the spices, trade and political relation was indicated to have existed since the Majapahit era (14th century) as mentioned in the Negarakertagama text about the names of Majapahit subordinates such as Luwu, Bantaeng, Butung, and so on. Tradesrelation between Sulawesi and Java then continued until the emergence of the Makassar kingdom in the 16th century (Villiers, 1990: 144).

Therefore, in this study Kendari port was placed as a traditional entity within the scope of maritime traffic becoming the link between other regions. Trade and shipping passing through the east coast of 
Sulawesi have not been revealed much because of the lack of both local and colonial sources. Even so, the record of trade and shipping activities in Kendari bay in the mid-19th century was found in the travel record as well as reports of Dutch official named Vosmaer (1839) and van der Hart (1853). As a pioneer of the trip, Vosmaer in 1831 accidentally passed the Kendari bay. He saw that there were residents who inhabited the bay which turned out to be from Bugis and Bajo tribes. Therefore, the Kendari researchers' statement that Vosmaer discovered Kendari bay was actually inaccurate and too colonial-centric, because there had been a Bugis fishing village there even though the bay he encountered was later named after his own name (Vosmaerbaai).

According to Vosmaer's estimation the fishing village had been formed around the 1820s which meant that it was existed between 10 and 15 years before his arrival to the bay. Vosmaer also observed the trade of Bugis and Bajo people at the time who bartered fish with other commodities such as rice and copra. In addition, Vosmaer also mentioned the relation between Bone and Laiwoi kingdom because Bone needed to establish its influence on the east coast of Sulawesi to replace Makassar, which had previously established the relation with the indigenous population (Vosmaer, 1839: 17). Van der Hart's note supported and strengthened Vosmaer's report, he came to Kendari bay in 1850 with two large ships named Argo and Bromo and was welcomed by Syahbandar Bone and the rulers of Laiwoi Kingdom. Van der Hart described the busy port with export commodities in the form of sago, rice and candles as well as imported commodities in the form of machete and knife, tobacco, liquor, sea cucumber, turtle shell, bark and some trinkets (van der Hart, 1853: 41).

Regarding Kendari bay selection as one of the destinations for outside migrants, HA Chalik said that until the mid-19th century, Kendari bay was a safe area that was not so affected by various political events that occurred in the surrounding countries as happened in Buton and Makassar, because Kendari was a land of hope for Bugis and Bajo people to settle down and build a peaceful life (Chalik, 1985: 112). The arrival of Bugis people subsequently occurred during Bone-Dutch war in 1824-1825 when the a Bone nobleman named Arung Bakung chose to leave Bone and then succeeded in establishing his influence in Laiwoi kingdom (Rabbani, 2011: 86).

Research on the history of the development of Kendari city has been carried out by a number of historical Kendari researchers, namely Chalik (1985), Rabbani (2011), Melamba (2011), Duke (2006) and Anwar Hafid et al. (2006). Their writing more or less have described the history of Kendari city from time to time using various perspectives. Chalik's writing is more about the depiction of the Southeast Sulawesi region from a social perspective while Hafid et al. (2006) argue that Kendari city was originally a settlement built by the European community so that it looked very colonial-centric compared to Melamba (2011 \& 2014) who used local sources to explain the development of Kendari city so that it can bring Kendari as a city that was born not only thanks to the contribution of Europeans but also comes from a long process with the contribution of local communities in it.

Even so, all the researchers agree that Kendari as a port does provide a significant role not only for the development of Kendari city in the future, but also as a trade and shipping center that has link with other ports especially on the east coast of Sulawesi. However, this connection has not been fully discussed by the researchers. In addition, to his research on the old city and new city of Kendari, Basrin Melamba also wrote about the history of the Kolaka port city, according to him Kolaka as a strategic port played an important role in connecting the points of trade and shipping of Bugis and Makassar people in Bone bay and also had relation with other regions in Southeast Sulawesi, this work does not address the Kendari region directly, but Melamba explains that Kolaka, as well as Kendari, has social and economic relation both from the sea and on land so that the economic progress and the construction of the two port cities can be achieved. (Melamba, 2011). Likewise, Said Duke also stated that the transformation of Kendari area into a commercial city and port was due to the role of the Dutch government, also because in this region the orientation of the coastal communities tend to the shipping and trade sectors (Duke, 2006: 18).

Another Rabbani study of coastal cities in Southeast Sulawesi still makes Buton the center of economic and socio-political activity in the region (buton-centric), this is reasonable considering that Buton Sultanate has a long history as the center of Islamic politics with Bau-bau as a famous traditional port city in the archipelago so that Kendari and Muna areas tend to be placed on the outskirt or even combined with Buton in a single unit, even though seen from the geopolitical aspect the three more or less are separated. The Buton-centric perspective is suggested by Rabbani because the data on Buton are indeed very abundant both the traditional and colonial sources. The study of Buton based on local sources is seen in Zuhdi's work, which states that the kabanti wolio (labu rope labu wana) poems can also be used to see how were the political, socio-cultural and economic conditions of the Buton people at that time. Therefore, it is 
undeniable that the development of Kendari port in relation to other regions is still very little to attract the interest of these researchers.

Furthermore, to see the activities that occur in the east coast of Sulawesi, it still needs to be revealed what the port network in the region was like. Ports located in this region include Kendari, Wawonii, Teluk Tolo (Tomori), Tobungku and Banggai islands. Meanwhile, field studies to find out what activities occurred in the eastern path of Sulawesi or those in the Banda Sea have only just reached the initial stage and have not produced a deep study. Although only the initial stage, the trade route involving Kendari as a port city can still be constructed by looking at the primary and secondary sources which indicate the link between Kendari port in the trade route from Makassar to Maluku islands. Therefore, the sources presented in the previously mentioned works are very useful in looking back at the strategic role of Kendari port in the social and economic scope in Southeast Sulawesi.

Then to fill the research on the history of Kendari, it is interesting to review the role of Kendari as a port that has its own dynamics along the east coast of Sulawesi by looking at the aspects that have not been touched by the previous researchers. This research, although very preliminary, is expected to open up further discussion within the scope of maritime studies in the eastern region of Indonesia, since to treat the nation's collective memory, the meeting points between ports in the archipelago become relevant study and part of the integration of the Indonesian nation from a historical perspective.

\section{Method}

This study uses a maritime concept to uncover the role of Kendari port with other regions in the trade and shipping context at the eastern coastal region of Sulawesi. Some maritime history researchers such as A.B Lapian explained the term maritime world as a world with sea as its center. The sea is seen not only as a shipping and trade route but also as a liaison between one region and another in the form of a port (Lapian, 2009). At least there are three main categories of port in Asia, namely entrepot, collecting center, and feeder point. Entrepot has a function as the main port for trading and exchange of goods from various countries, while Collecting Center is more as a center for collecting goods or crops from the hinterland that will be used alone or taken elsewhere. The feeder point is a smaller supporting port and is located in strategic route, so it is more as suppliers of goods at the collecting center port or directly to entrepot (Leong, 1990: 23-29).

Based on these characteristics, this study sees that Kendari port is included in the collecting center port category because it gets a certain commodity supply from feeder points. Therefore, this type of port usually has a good natural port, a place for merchants to take raw materials from various hinterland areas to be exported to other regions and has a local market, rich hinterland, and a place to collect goods from the surrounding small ports. (Leong, 1990: 23).

This research uses primary and secondary sources such as books, encyclopedias, journals and colonial records regarding what activities occured in Kendari port. Colonial sources can be accessed at the National Archives and online, while some secondary sources can be accessed through several libraries such as the National Library in Jakarta and the University of Indonesia Library in Depok.

The method used in this study is a historical method consisting of Heuristics, Verification, Interpretation, and Historiography. Heuristics is the activity of seeking and collecting historical sources both primary and secondary sources. The next stage is verification, namely criticism of the source by sorting out sources that can be used with sources that cannot be used as references in this study. Then after criticism of the source, the Interpretation is then carried out by analyzing the sources that had been obtained into a description of historical facts, then classified and interpreted according to the research objectives. The last procedure is historiography which is to realize historical data that has been collected, analyzed and interpreted so that it becomes a chronological historical writing.

\section{Connectivity of Kendari with Other Regions}

This research shows that although at the end of the 19th century Kendari port was a small fishing village for collecting center, this port was traditionally connected to other regions through several routes, namely the Makassar-Ternate trade route which originated from Makassar, Buton, stopped at Wawonii and then directly to Ternate. Due to the high traffic of ships passing through Wawonii Island, people around Kendari bay used to sail and exchange goods and had a journey to study Islam there and vice versa, Muslim traders who stopped at Wawonii could enter through the bay to trade and spread Islam in this region. The second route was the direct trade route through Kendari port which utilized Bokori island as a connecting island for Bugis and Tolaki merchants who would trade to Tolo bay and Tobungku. 
In the colonial context, Kendari port was built and prepared slowly to become the center of Dutch power in the eastern region of Sulawesi. This development was the basis for Kendari port to transform into one of the modern ports in Sulawesi. This study shows the ups and downs of Kendari port which had become a major port visited by KPM ships, until the Japanese period where Kendari became a Military port, the starting point of Japanese power to conquer other territories in Sulawesi.

Furthermore, in this study, the writer agrees with the opinion that Kendari port was traditionally built by local authorities and local residents who worked as fishermen and it served as a Collecting Center for commodities carried by Bugis and Bajo merchants, had feeder point area in the form of rich hinterland with crops, nd had surrounding islands like Wawonii and Bokori. Dutch colonial intervention supported by the rulers of Laiwoi kingdom made Kendari a stable and strategic port city and became an effective and economical connecting port for trade and shipping in the region.

\section{Kendari in Traditional Trade Route}

Kendari Port was originally a small fishing port which was less noticeable compared to other surrounding areas. Most of the residents around Kendari bay were migrants from Bugis and Makassar tribes who were oriented to sea trade. The reports of Dutch officials in Buton and Kendari stated that until the mid-1930s Kendari had the base of Bugis and Makassar residents spread in several regions such as Tonggano, Abeliti, Wawotobi, Lambuya, Lahundapo, Abeli and Konda. In addition to work as traders, they also work as farmers. The areas where they live were indeed rice barns in Southeast Sulawesi (Taatgen, MVO, 1933).

Geographically, Kendari port is located in the northern part of Kendari bay. This bay is located on the east side of Southeast Sulawesi peninsula, extending from east to west and covered by Bungkutoko island which blocks the view of the bay from the outside so it is quite safe from the wind breeze from the east. But based on van der Hart's experience, he explained that the entrance to the bay was very difficult to pass if inexperienced, it was because the east wind blows directly on the ships before they reached the uninhabited island of Bungkutoko (van der Hart, 1853: 48). The northern side of the bay is deeper than the south side so that it can be navigated by large ships. After entering the narrow bay mouth to the west, the bay area widened further. There are only two large rivers which empties into the west side of the bay, namely Lepolepo river and Kambu river, while on the southern edge there are several small river estuaries namely Lapulu, Anggoeya, and Andonohu, the north side are Sodohoa, Benu-continent, and Tipulu, while in the northeast there is Mandonga river (Chalik, 1985: 2).

The geographical location shows that even though it slightly curves inward, in fact Kendari bay is in a very strategic location for loading and unloading of goods and it also becomes the route to the hinterland using the river. Furthermore, to re-map Kendari port as a link between trade and shipping routes in the eastern part of Sulawesi, the first argument in this study is to look at Kendari as part of the Bugis and Buton shipping route through Wawonii island, which coincided with the entry of Islam into the region Konawe kingdom. As the record, during the first half of the 19th century, the sea trade of Bugis people still remained busy in various regions of the archipelago. Even after Gowa was conquered, Bugis kingdom in South Sulawesi was actually still sovereign even though the Dutch repeatedly tried to interfere in their internal affairs (Pelras, 2006: 362).

In addition, the association of Kendari region with the Buton trade route can be traced since the efforts of Buton Sultanate in preaching Islam to the land of Konawe (Kingdom before Laiwoi) in the mid16th century. Aesther Velthoen's explanation strengthened this argument that actually the trade relation between community groups in East Sulawesi had been going on since the 16th century because commodities produced from this region sold well in the market and were connected with the trade routes passed by international traders (Velthoen, 1997: 367) International traders in this context were originally Muslim traders who stopped at the central regions of the Islamic Kingdoms such as Buton and Maluku.

Local sources mention that Islam entered Konawe Kingdom sixteen years after Buton accepted Islam. Buton changed into the Islamic Sultanate since 1541, after Islam was brought by an ulama named Sheikh Abdul Wahid. Sheikh Abdul Wahid succeeded in the Islamization of King of Buton VI who later held the title Sultan Murhum (Mustafa, 2009: 88). Islam entered Konawe kingdom through two routes namely official and spontaneous route. The official route was marked by the arrival of Buton Sultanate delegate named La Embo to ask Mokole Melamba from the Konawe kingdom to convert to Islam but his effort failed. Whereas, the spontaneous route for Islam to enter Konawe region was through Bugis, Makassar, Ternate, and Buton traders who came to Konawe coastal areas such as Tinanggea, Lasolo, Sampara, Toli-toli, and Bajo village in Kendari. After failed to convert the King of Konawe (Mokole), La Embo then headed to 
Wawonii island and succeeded in the Islamization of the residents there so that Wawonii Island developed into a center of Islamic teaching which was influenced by the Sultanate of Buton (Aswati, 2011).

In addition to have cultural proximity to Konawe, Wawonii Island was also a disputed territory between Buton and Ternate. Even so until the end of the 19th century Wawonii Island still remained under Buton control and only gained independence in 1870 by stopping tribute payment that was usually paid every year (Melamba, 2011). It this island, the Mokole Konawe successor named Lakidende in the mid-18th century was sent by his father Mokole Melamba to learn Islam. Then after returning from the island, Lakidende learned again to read the Qur'an in Tinanggea region, which was one of the ports belonged to Konawe Kingdom on the southern coast and geographically closer to the Buton region. After being crowned as a king, Mokole Lakidende then proclaimed Konawe as an Islamic kingdom. As Lakidende converted into Islam and the spread of Islam to the hinterland of Konawe, then the Bugis and Makassar traders increasingly visited the Konawe kingdom to trade (Aswati, 2010: 21). Tamburaka said that in order to support the success of Islamic da'wah in Konawe Kingdom, Mokole Lakidende invited twelve preachers from Buton led by La Ode Tekke to teach Islam in Unaaha, the center of Konawe kingdom (Tamburaka, 2011: 24).

Historically, Wawonii island was a stopover for Buton traders who would continue the road to Tobungku, Tolo Bay, Banggai to reach Ternate or enter Tomini Bay. On the other hand, the location of Wawonii, which was on the trade route between Ternate and Buton, enabled traders from Ternate to reach Wawonii to trade and also spread Islam. According to Basrin Melamba, during the trip, the traders and Islamic preachers had succeeded in the Islamization of the residents of the northern coast of Konawe such as Bandahea, Molawe, and Lasolo through the island of Wawonii, as well as the southern coast through Tinanggea port (Melamba, 2011: 161). In contrast, traders from Ternate also visited Wawonii and also the eastern and northern coasts of Konawe kingdom to trade and spread Islam. Due to its very close geographical location, it can be said that Kendari bay region was also affected by the visit of the Muslim merchants resulting in Bugis (already Islamic) fisherman settlements mentioned by Vosmaer during his visit in 1831.

The second argument shows a direct trade route between Kendari bay and the route to Tobungku via Bokori island and Tinanggea port. In the 17th century, a note from Spellman quoted from Zuhdi showed the busy trade traffic from Makassar to Tobungku and Banggai islands which sell iron axe, turtle shell and pepper (Zuhdi, 2018: 54). This evidence was strengthened by Vosmaer who mentioned the trade route to Tobungku which was very crowded with trade, especially Bugis and Makassar traders who came to this area every year using Pa'dewakang and Kora-kora boats. Tobungku, according to Vosmaer's record, was an autonomous Ternate subordinate country, so it was quite prosperous and actively engaged in trade along the east coast of Sulawesi and Banggai islands, from there the trade was then continued to Tolo bay. The main trade commodities were sea cucumber, rubber and wax. Tobungku area is the star of the traders because the location of the Tobungku port that is quite safe for ships that will dock, in addition it also offers sufficient protection from strong southeast wind blow (Vosmaer, 1839: 41).

Konawe people themselves or perhaps Laiwoi (all of them are Tolaki ethnic) were already accustomed to trade along this route to Tobungku. Vosmaer noted that the residents living in the Moramo region to Sampara (perhaps most of them also Bugis and Bajo) had traded to Tobungku by first exchanging rice and sago by ship or boat in Buton. To go to Tobungku they used Pa'dewakang boat which was ordered by a person from Bajo, Selayar, or Ambon tribes. The traders then stopped at Bokori island where the residents who came from the northern coast of Konawe bartered to meet their daily needs. Poelinggomang said that Tolaki people who lived in the Tomori or Tolo bays were 150 men, they came to collect and sell forest products, traded in small scale and then returned home to their land (Poelinggomang, 2008: 25).

When going back, the merchants transported the crops collected from the hinterland, sometimes the they were taken to Bokori island and then accommodated by other traders to be brought to Buton, Makassar or Java (Chalik, 1985: 19). In addition, what is interesting is that there is a trade partnership between local residents organized by joint venture where everyone had shares in the cargo (Vosmaer, 1839: 35). Unfortunately, it is not further explained as to what and how this trading partnership operated so that it needs further study.

\section{Colonial Hegemony}

According to the Encyclopaedie van Nederlandsch-Indie, Kendari Bay is described as a calm sea area where small-scale and busy trade takes place with view of hundreds of wooden huts (stilt houses) built high on the edge of the sea. To go along those houses, people need small boat and a long bamboo stick for rowing. It seems that Kendari name meaning is etymologically correct because Kendari means Kandai or a bamboo stick to row a boat through shallow and calm waters (Stibbe, 1919: 300). Therefore, the development of 
Kendari port is closely related to the role of Kendari bay as a strategic natural port. J.N Vosmaer noted that Kendari is a bay that is calm, beautiful, strategic and has good economic prospects. He wrote this description of Vosmaer after he met the King of Tebau, the ruler of Laiwoi kingdom, who had the title Lakino Konawe (Man of Konawe).

The diplomacy created an "alliance" agreement because it appeared that the King of Tebau really hoped for the presence of "strong people" for the common interest in facing the attack of Tobelo pirates. Tebau also tried to revive trade which had suffered a setback due to the departure of Arung Bakung from the region, so he welcomed the arrival of the Dutch warmly and offered alliance (Vosmaer, 1839: 15). In addition to that, the purpose of Tebau's interest to always form alliances with outsiders is also to challenge Buton's dominance who claiming supremacy over Laiwoi region, so that the alliance rose Tebau's status as a legitimate ruler equal to other kingdoms around it (Velthoen, 2010: 209).

Before Vosmaer's arrival, the influence of Arung Bakung had already been embedded in Laiwoi. Arung Bakung was a nobleman from the Bugis Kingdom of Bone, he was said to have departed from Bone around the 1820s and settled in the Sampara estuary, one of Laiwoi's royal regions. Bakung then made an adventure to take control of Buton's subordinate namely Tiworo kingdom. His exile from Bone was the result of BoneDutch war (1824-1825). Arung Bakung the liberate Tiworo and Muna from Buton but he suffered loss so he had to find a new place. The King of Laiwoi accepted it by offering an agreement of friendship for his assistance in securing the Kendari bay area. The king then appointed Arung Bakung around the Kendari bay as the leader of Bugis people. Thanks to the management of Bakung, Ranomeeto region which became the center of Laiwoi's government and trade became very busy (Rabbani, 2011: 17).

In 1830 he left Kendari bay with his subordinates. Arung Bakung was regarded as the first leader of the Bugis tribe in Kendari Bay as well as dethroned the trah (a group of individuals who have mutual relationships with each other) of Laiwoi thanks to his descendants who married Maho, the daughter of Tebau king (Chalik, 1985: 41). The control of Bugis trah over Laiwoi crown reflected the success of the Bugis strategy in state diplomacy at that time. The departure of Arung Bakung was estimated to occur due to a dispute with local residents. Unfortunately, it was not stated whether he was leaving because of a dispute with the residents or Mokole (king) Laiwoi, whose departure also brought the majority of Bugis and Bajo traders who were living in the bay of Kendari with him.

This incident had an impact on the drastic decline of trade and security in the region because it was vulnerable from the attacks of Tobelo pirates. Despite experiencing a setback in the economy, based on Vosmaer's information, it shows that there were still Bugis and Bajo residents left who worked as fishermen and also carried out the trade and shipping activities there. They generally lived along the coast of the bay which was concentrated on the north and west sides of the bay. This shows that even though it is no longer busy, trade and shipping activities remain alive even on a smaller scale.

When he saw his relationship with king of Tebau running smoothly, Vosmaer wrote the advantages of Kendari bay as a consideration for the central government in Batavia. Vosmaer noted in detail the geographical location, the economic condition of the population, especially the trade in sea turtle shells favored by Chinese traders, therefore Vosmaer felt that through writing he needed to introduce the types of sea turtle shells commonly obtained by Bajo people. Vosmaer also explained that Bajo people were trained to recognize turtle shells in terms of their distinctive pattern and color so they were very expensive if sold to Chinese traders in Makassar. Finally, at his conclusion about the real condition of Kendari port, Vosmaer stated that Kendari and its surrounding areas were very suitable to serve as one of the important Dutch government, military and commercial centers in the eastern region of Sulawesi, especially to secure the area from pirate attacks (Vosmaer, 1839: 84). From this report it clearly shows that the turtle trade between Kendari and Makassar had been going on for a long time since Bajo people began selling sea products to Bugis traders.

A year later, in 1832 Vosmaer returned and kept his promise to the King of Tebau to establish a palace and lodge on the north side of the bay which was welcomed by the king by moving the Laiwoi royal administrative center from Lepo-lepo to Kendari bay. This transfer became the beginning of the development of the northern part of Kendari bay from an area that was only filled with fishing villages into a busy central government city. In order to re-develop the function of the Kendari port city in the trade sector, Vosmaer then invited the Bugis and Bajo traders to return to live and trade in Kendari bay so that the area slowly became extremely busy again (Vosmaer, 1839: 90). The rapid response from Bugis and Bajo traders and fishermen on an offer from Vosmaer is indeed understandable from the importance of their interests to keep trading and navigating in the region without any interference.

To understand better the trading activities of the Bugis people in the broader context during the first half of the 19th century around the time, Vosmaer began to travel along the east coast of Sulawesi, Christian 
Pelras's study was a valuable summary. Pelras explained that most of the large Bugis trade boats were in the main ports such as Makassar, Mandar, and Pare-pare to collect the commodities they would bring to Singapore. From Maluku, East Nusa Tenggara, Southeast Sulawesi and parts of Australia, they carry pearl ovary, shell, turtle shell, gelatin, sea cucumber and bird nest to be exchanged for gunpowder, European woolen cloth, sheet, kitchen utensil and others. They usually departed for Singapore in October when the wind blows the strongest and sailed back to Sulawesi in December or January, while the trip to Maluku was carried out in December and March in the direction of the west monsoon through the port east of South Sulawesi, turning north through Buton, Kendari, Tomini Bay, Ternate, North Halmahera, and ending in Papua. While the route south passed Buton, Ambon, Aru and Kei Islands. Bugis ships then returned to South Sulawesi or traveled to Flores and Sumbawa in April and August when the east wind blew hard (Pelras, 2006: 363).

Due to the free trade activities of the Bugis people, the Kendari port then quickly transformed as a large port supported by modern infrastructure so that large vessels could anchor comfortably. Because of that, during the Dutch East Indies government, Kendari port also functioned as a collecting center with wider coverage than before, with commodities mainly in the form of marine and forest products in the form of copra, rattan and resin imported from the hinterland, besides that there were also various goods from all parts of the archipelago that came through the Buton and Makassar routes (Rabbani, 2011: 93). Note of Van Der Hart lists the quantities of commodities traded in this region during his visit in 1850. These commodities as listed in the list below are candle (was), sea cucumber and turtle shell and turtle.

From the price list above, der Hart said that the average number of sea cucumbers that entered the Kendari port was quite large, which was between 500 and 600 piculs per year as well as pearl oyster which would then be exported again to Makassar and Buton. These commodities were usually collected from various locations including Tobungku, Banggai and Sula Islands. In 1850 when Der Hart visited Kendari bay, the role of Bugis Syahbandar in Kendari port had been well well, but his role was only as an official confirmed by Bone kingdom, not by the Laiwoi kingdom. Syahbandar took a tax of $5 \%$ from every in and out item (van der Hart, 1853: 41).

Although Kendari port was controlled by Bone, the Laiwoi Kingdom was still recognized as the legitimate ruler of the region due to the alliance between Laiowoi and the Netherlands. In 1906, King Saosao (1871-1928) signed Perjanjian Panjang (long contract) which he had signed in 1885. Thus, Laiwoi was mentioned as the only kingdom in Sulawesi that was not bound by a short agreement (korte verklaring) with the Netherlands. But with this agreement the Dutch gained access to control all the remnants of Konawe Kingdom nobles in the hinterland that were still independent, the latter were conquered through a military expedition (Bhurhanuddin, 1987: 49). As a result, in 1918 the last resistance of the Konawe nobles was broken down. The Dutch then began to build the city infrastructure such as highway, market, worship facility, military dormitory and office.

In 1912, a 62 kilometer long road was built that expanded from Kendari bay to Wawotobi which was the rice producer to facilitate transportation, with the opening of the road the process of trade commodity transport from the hinterland became faster and easier. In addition, the population also increased, in 1913, the population of Laiwoi Onderafdeling was 52,000 with 13,500 males (Stibbe, 1919: 505), and of course this number was very profitable for the local economy when Kendari became increasingly important economically after the imposition of excise on export-import on ships that docked and various types of tax (Rabbani, 2011: 94).

Therefore Kendari port naturally became busy with ship traffic, especially with the making of Kendari port as one of the destinations from KPM ships (Koninklijk Paketvaart Matschapij) which routinely visited Kendari bay at certain times carrying goods from Makassar (Asba , 2007: 102). Even so, the role of pa'dewakang or Bugis boat had not faded at least until the beginning of the Japanese period as the carrier besides the large KPM ships, because not all commodity production centers could be reached by KPM. In fact, a competition between KPM and local ships tend to occur which proved that the economy was good because of the smooth trade (Dick, 1986).

Trade commodities produced by Kendari city during the Dutch colonial rule came from the need for food to be exported to other regions. Because of the need for export commodities, the residents were introduced to the types of plant and agricultural techniques that were previously unknown to the population. The Tolaki tribe who previously planted rice by shifting cultivation was then introduced to rice cultivation techniques. From then, rice farming centers was born located in the Lambuya, Abeli and Ranomeeto districts. In addition to Kendari, the Netherlands also introduced new plants in Buton and Muna areas such as teak, copra, green beans, pulses, tobacco, coconut and corn. Kendari also donated its superior commodities 
in the form of rattan and resin. Together with Buton, Luwu, and Palopo, Kendari owned shares in the export of Rattan from all Sulawesi as shown in the table of Sulawesi rattan export.

Rattan collected from Kendari was then taken to Buton and kept by the traders there. Rabbani said that there was a rattan hoarding and colleting company owned by Oi Steven and Lim Chin Kie in Buton. The results of the landfill were then transported by boat and KPM ships headed to Makassar. The export value obtained from rattan trade showed good results throughout 1913-1924 with a total value of 8.9 million guilders. The benefits obtained by Buton and Kendari (Laiwoi Kingdom) throughout the 1920s from the sale of rattan, resin, and kapok amounted to 2000 guilders per year (Rabbani, 2011: 33). These results indicated that trading activities in Kendari had increased from year to year with the increasing commodities.

\section{From Commercial Port to Military Port}

Activities that took place in Kendari port then faded in Japanese period. Kendari was no longer acts as a commercial port but it was used as a military port of the Japanese navy. In 1942 the situation in the Dutch East Indies was disturbed because of the Japanese attack. Among the newspapers covering the attack was Nieuwsblad van het Noorden who reported on the success of several Japanese soldiers in the attack on the Dutch East Indies. It was reported that on January 26-27, 1942, Japanese fighter aircraft had bombarded Kalimantan, Seram, Sulawesi and Buru islands. Cities in Kalimantan and Sulawesi were quickly occupied by Japanese troops including Kendari, which was occupied on January 26 after clearing the resistance left from the Dutch forces (KNIL) in the region ("Nieuwe", 1942).

Apparently Japan was keen to see Kendari as a strategic place or at least one of the weakest but strategic points that could be easily controlled, this was evidenced almost without any fierce resistance from the Dutch East Indies military in Kendari which instead evacuated to Makassar. The Japanese strategy was most likely to be obtained before the war when Japan began spreading spies in Kendari city. The spies were spread in several areas in the cities of Kendari, Muna and Bau-bau. Around the 1920s in Kendari a Japanese named Tomutsu Ohitsi who married a local woman and had three children came. Ohitsi died in 1930 and his gravestone was imported directly from Japan. Apparently Ohitsi was a Japanese naval officer. Ohitsi's arrival in Kendari was followed by Maeda who opened an ice factory. Maeda was known to have met a number of Japanese spies just before the war (Bhurhanuddin et al. 1987: 111).

The actions of the Dutch after the outbreak of the Greater East Asia War (1938) first were to arrest Japanese people who had lived in Kendari for a long time and distribute leaflets containing the determination of the Dutch East Indies government to fight Japan which was accompanied by threats to the rebels. Apparently the Dutch government was worried that the people would be easily convinced by Japanese war propaganda because the period of the Dutch occupation stabilization in all Southeast Sulawesi areas was still relatively new around 1918. From this, it was seen that the Dutch were very afraid that the Southeast Sulawesi people would easily support Japan because of long time resentment. This concern was proven after the Japanese arrived, the Kendari people welcomed him enthusiastically and the kings who ruled in Southeast Sulawesi including the Laiwoi kingdom chose not to take any political action to support Japan (Bhurhanuddin et al., 1987:107).

This action originated from the failure of the colonial government to attract sympathy from the colonial people when the beginning of World War II broke out. The state of the Netherlands that was occupied by Germany apparently made the Dutch East Indies government insisted to maintain the status quo only to maintain the prestige as an influential country in the world of international politics, according to Onghokham one of the reasons that accelerated the collapse of the Dutch East Indies was because none of the people on the colonized area who gave helped the Dutch facing Japan (Onghokham, 1987).

Japan entered Kendari, led by Admiral Nakamura. Japan could quickly immobilize all the remnants of Dutch power in the region. The main employees of the Dutch East Indies and several platoon of KNIL forces had been evacuated to Makassar, only one platoon remained or left behind in Kendari because it was very easy to conquer. Furthermore, Japan built forts, especially around Kendari's two airfields. Kendari City was then rearranged as a city that had an important role in Japan's defense while the Kendari port became a ship workshop, maintenance, and an entry center for Japanese army supplies. From Kendari, Japanese forces then conquered Makassar in February 1942 and then headed to Timor. While Muna and Buton were conquered in December 1942 (Bhurhanuddin et al., 1987: 114).

Initially Japan was well received by local residents, but the original nature of Japanese troops began to appear when the military government imposed strict regulations accompanied by severe penalties even for small mistakes. Especially when Japan imposed Romusha, a work without being paid to build infrastructure, defense centers and Japanese military facilities. From the perspective of local residents, the Japanese 
occupation period was seen as the hardest period experienced by Kendari residents. Although it was hard, the residents felt a new experience that they had never felt in the Dutch era, namely the opportunity to practice the military and organize strictly and discipline manner.

After the arrival of Japan, there was an automatic decline in trade in Kendari port because all economic activities were in Japanese hands. KPM ships stop visiting Kendari and local ships were prohibited from sailing. The traditional trade route connecting Kendari with the area on the east coast of Sulawesi was automatically cut off with the focus of Kendari as a center for Japanese defense and supplies in Eastern Indonesia. Then in 1946 when the NICA government came back, the effort to revive trade in Kendari was done. Even so the trade situation was still very difficult (Chalik, 1985: 81).

On the Local Government Files of level II Kendari can be seen that Maamoen Dg. Mattiro as Bestuur Asistent of Kendari reported this difficulty by concluding that the black market could be eliminated if the goods were massively imported by the NICA government. In addition, the expensive transportation costs were not comparable to the selling price so the profits were very low. This can be seen through market condition during the Japanese government and NICA. The market condition in the second period of foreign government was very quiet and limited to the basic needs/food of agricultural products and local marine products (Mattiro, 1946).

After NICA had established its position in Kendari, the trade began to return to normal with several commodities being transported to hinterland. Presumably the commodity taken came from Makassar via the KPM ship, but it did not rule out the possibility of commodities coming from other regions besides Makassar because of many Pinisi Bugis ships which were still the prima donna of inter-island transport at the time so that the sea trade after the collapse of Japanese power back to normal. So by looking at this possibility, it is very possible to conduct further studies regarding the development of traditional trade remnants that still take place along the east coast of Sulawesi in Japan and NICA. However, even though the relation with the eastern Sulawesi region such as Tolo Bay, Tobungku, Banggai to Maluku became unclear, trade relation with Buton and Makassar became even more intense, it was evidenced by the establishment of the copra warehouse belonging to the Copra Foundation of Makassar in Kendari in 1946 which became the basis of Copra trade relation which was more intense with Kendari in the following years (Chalik, 1985: 81).

\section{Conclusion}

The activities of the Kendari port originating from the trade of the Bugis, Bajo and Tolaki people have been existing since the 16th century and were increasingly busy when Islam entered the Konawe kingdom during the Mokole Lakidende period. On the way to reach Tobungku and Ternate, Bugis and Bajo sailors had passed by in front of Kendari bay following the international trade route that passed on Wawonii island. Departing from Wawonii island, the Konawe royal community until the Laiwoi kingdom could trade smoothly with the traders from Ternate, Makassar and Buton. In addition, traders who came from Konawe or Laiwoi sailed by hiring a captain from Bugis, Ambon or Buton tribes to navigate their trade routes to Bokori island then proceed to Tobungku, bay of Tolo, which ended up in Ternate and vice versa until it reached larger port like Makassar and Java.

In addition, the connectivity of Kendari port with its neighboring regions shows that traditional trade routes connecting one port with another port in East Sulawesi can be constructed from the reports of J.N Vosmaer and van der Hart. The development of Kendari port city had increased rapidly since J.N Vosmaer's arrival in the region. Vosmaer's role not only illustrates the situation in Kendari bay, which at that time was still a fishing village, but also succeeded in encouraging the Dutch government to develop Kendari as an important port in the region in addition to control the shipping and trade activities in the region.

The Dutch then entered into an agreement with the Laiwoi authorities and slowly built the city and port infrastructure in Kendari so that it became a modern port city, in which the port's role and function increased, one of which was connected to the official KPM route. Commodities exported from Kendari were agricultural and marine products, while the imported goods were in the form of various weapons, tobacco, liquor, sea cucumber, turtle skin, and others. This connectivity was continued by Japan in developing Kendari port infrastructure as a repair center for warships and Japanese army supplies in Sulawesi. The ups and downs dynamics of Kendari port indicate that Kendari's role plays an important role in the region. The struggle for influence and hegemony that occured even further strengthens Kendari as a strategic and economical area for any force that wants to intervene in this region. 


\section{References}

"Nieuwe Japansche Successen in Nederlandsch-Indie", Nieuwsblad van Het Noorden, 30 January 1942.

Asba, Abdul Rasyid. Kopra Makassar: Perebutan Pusat dan Daerah: Kajian Sejarah Ekonomi Politik Regional di Indonesia, Jakarta: Yayasan Obor, 2007.

Aswati M. "Masuk dan Berkembangnya Agama Islam di Kerajaan Konawe." Jurnal Selami IPS XVI, no. 34, 2011.

Aswati M. Sejarah Lokal Sultra: Daerah Kendari dan Kolaka, Kendari: Hand Out Prodi Sejarah FKIP UNHALU, 2010.

Bhurhanuddin, B. et al. Sejarah Kebangkitan Nasional Daerah Sulawesi Tenggara. Jakarta: Departemen P \& K, 1987.

Chalik, Husein A. et al. Sejarah Sosial Daerah Sulawesi Tenggara, Jakarta: Depdikbud, 1985.

Dick, H. W. The Indonesian Interisland Shipping Industry, An Analysis of Competition and Regulation, Singapore: ASEAN Economic Research Limit, Institute of South Asian Studies, 1986.

Duke, S. "Dari Kota Kolonial ke Kota Niaga: Sejarah Kota Kendari Abad XIX-XX", Makalah disampaikan pada Konferensi Sejarah Nasional VIII, diselenggarakan oleh Direktorat Nilai Sejarah, Direktorat Jenderal Sejarah dan Purbakala, Departemen Kebudayaan dan Pariwisata, 13-16 November 2006.

Hafid, Anwar \& Safar, Misran. Sejarah Kota Kendari. Bandung: Humaniora, 2006.

Lapian, A. B. Orang Laut, Bajak Laut, Raja Laut: Sejarah Kawasan Laut Sulawesi Abad XIX, Depok: Komunitas Bambu, 2009.

Leong Sau Heng "Collecting Centers, Feeder Points, and Entrepots in the Malay Peninsula 100 B.C. -A.D. 1400", dalam J. Kathirithamby-Wells \& Villiers, John (ed), Southeast Asian Port and Polity: Rise and Demise, Singapore: Singapore University Press, 1990.

Maamoen Dg. Mattiro de Beestuur Assistant van Kendari, Verslag Boelan Oktober 1946, 13 November 1946.

Masashi, Haneda ed. Asian Port Cities 1600-1800, Local and Foreign Cultural Interactions, Singapore: National University of Singapore Press, 2009.

Melamba, B. "Sejarah Singkat Kabupaten Konawe Kepulauan”, Makalah intisari dari: Basrin Melamba et al., Penyusunan Sejarah Konawe Kepulauan. Kendari: Bappeda \& PM dan Lembaga Penelitian Universitas Haluoleo, 2014.

Melamba, B. Kota Pelabuhan Kolaka di Teluk Bone, 1906-1942, Bali: Pustaka Larasan, 2011.

Melamba, Basrin dkk. Kota Lama Kota Baru Kendari: Kajian Sosial, Politik, dan Ekonomi, Yogyakarta: Teras, 2011.

Mustafa P. dkk. Sejarah Perkembangan Pendidikan Islam di Sulawesi Tenggara, Kendari: Universitas Muhammadiyah, 2009.

Onghokham. Runtuhnya Hindia Belanda. Jakarta: Gramedia, 1987.

Pelras, Christian. Manusia Bugis. Jakarta: Penerbit Nalar, 2006.

Poelinggomang, Edward L. Kerajaan Mori: Sejarah dari Sulawesi Tengah. Depok: Komunitas Bambu, 2008.

Rabbani, La Ode. "Menafsir Ulang Perkembangan Kota Kendari: Implikasi dari Kekacauan Sosial Sebelum \& Sesudah Kemerdekaan”. In Yudhi Andoni ed. Jaringan Kebangsaan Antar-Nusa: Prosiding Seminar Nasional 71 Tahun Indonesia Merdeka. Padang: Laboratorium Sejarah Universitas Andalas, 2016.

Stibbe, D.G. Encyclopaedie Van Nederlandch Indie. Leiden: S-Gravenhage \& Martinus Nijhoff, 1919.

Taatgen, F.H.P. Bestuursmemorandum Bettrefende de Onderafdeeling Kendari en Buton, Memorie van Overgave Celebes en Onderhoorigheden, Jakarta: ANRI, 1933.

Tamburaka, Rustam E. Sejarah Sulawesi Tenggara dan 45 Tahun Sulawesi Tenggara Membangun, Kendari: Unhalu Press, 2011.

van der Hart, C. Rondom Het Eiland Celebes en Naar Eenige der Moluksche Eilanden, Leiden: Te's Gravenhage bij K. Fuhri, 1853.

Velthoen, Aesther "Wonders, Robbers, and Bad Folk: The Politics of Violence Protection and Trade in Eastern Sulawesi 1750-1850". In Anthony Reed (ed), The Last Stand of Asia Autonomiesm Responses to Modernity in the Diverse States of Southeast Asia and Korea, , London: MacMilan, 1997.

Velthoen, Aesther. "Pirates in Periphery: Eastern Sulawesi 1820-1905". In Pirates, Port, and Coast in Asia: Historical and Contemporary Perspectives, edited John Kleinen \& Ossenwijen, Manon. Singapore: ISEAS Publishing, Singapore, 2010.

Villiers, John. "Makassar: The Rise and Fall of an East Indonesian Maritime Trading State (1512-1669)". In Southeast Asian Port and Polity: Rise and Demise, edited by J. Kathirithamby-Wells \& John Villiers. Singapore: National University of Singapore Press, 1990. 
Vosmaer, J. N. Korte Verklaring beschrijving Van Het Zuid-Oostelijk Schiereiland van Calebes in het bijzonder van vosmaerbaai of van Kendari; met berigten omtrentden stam der Badjos; dalam varhand V.H Bataviaasch Genotsch ap van kunsten en weterschappen XVII de Deel, Batavia, 1839.

Zuhdi, Susanto. Sejarah Buton yang Terabaikan: Labu Rope Labu Wana, Jakarta: Wedatama Widya Sastra, 2018. 